\title{
The Interaction of the Banking and Real Sector of the Economy of Kazakhstan
}

\author{
Lyazat Azimovna Talimova
}

\section{Gauhar Muratovna Kalkabaeva}

\author{
Department of «Banking», Karaganda Economic University of Kazpotrebsoyuz, Karaganda, Kazakhstan \\ Email: aisanatazhbaeva@mail.ru
}

\section{Doi:10.5901/mjss.2015.v6n3s3p313}

\begin{abstract}
The article describes the main trends in bank lending to the real sector of the economy in the post-crisis period under the influence of certain macroeconomic factors. The authors made a comparative analysis of indicators of development of Kazakhstan and other CIS countries on the basis of statistical data of the IMF for the period of 2009-2013. During the period analyzed in the study group of countries was the resumption of economic growth, decline in the annual inflation rate as a result of ongoing programs of restructuring the economy and the financial sector. Starting in 2011, Kazakhstan has become a positive trend of growth in bank lending. However, the credit activity of banks after the crisis is still not restored. The research identified the main obstacles to strengthening the interaction of credit banking and real sectors of the economy, such as with an unbalanced lending, short-term funding of banks, the high concentration of credit risk in the real economy, the inefficient use of credit, high credit cost and others. Proposed some measures to improve the credit activity of the second-tier banks, such as interest rate subsidies to fund the priorities of socio-economic development or administrative restrictions of rising interest rates, the provision of state guarantees for loans to the real sector of the economy, the decline in non-performing assets in the balance sheets of banks, the development of the regional elements of the banking system, etc.
\end{abstract}

Keywords: credit, the real economy, the banks, the refinancing rate, factors

\section{Introduction}

The banking sector plays a significant role in enhancing the competitiveness of the country and largely determines the rate of economic growth. During the years of independence of Kazakhstan's banking sector has reached high levels of development. Of course, this result is received and accepted in the country programs, restructuring of the economy and the financial sector.

At the same time, Kazakhstan's economy is vulnerable to external risks and financial instability in the world. Frequent crises in the monetary sphere are reflected in the real economy and the country's economic security. The instability of the macroeconomic environment at global and national levels generates new types of risks. These risks include the risks of growing capital outflows from emerging markets, reduce the cost of national currencies against the foreign key, stress liquidity in the banking sector, the low level of profitability of most companies and many others.

It is known that the instability in the global financial markets in 2007-2008, has affected the pace of development of Kazakhstan's economy. Kazakhstan's banking sector was among the first felt the negative impact of the global financial and economic crisis. This was shown to reduce the possibilities of domestic banks to attract external financial resources and, consequently, reduction in lending domestic economy. Government and the National Bank of Kazakhstan was quickly adopted and implemented a set of priority measures aimed at mitigating the adverse effects of instability in global financial and commodity markets. In 2009, was adopted the Concept of development of the financial sector of the Republic of Kazakhstan in the post-crisis period. Public policy began to focus on the implementation of macro-prudential regulation and, accordingly, enhancing the role of the National Bank of Kazakhstan as a body of macro-prudential regulation. Along with the implementation of anti-crisis measures in 2010, the state program of forced industrial and innovative development. In 2011-2013, took part in PAIID significantly intensified domestic and foreign investment in the processing sector of the economy and the country's infrastructure.

The novelty of the article is to try an integrated approach to solving the existing problems in the banking sector due to the development of Kazakhstan's economy. Will identify the organizational and economic factors affecting the return movement of credit and preventing the fullest realization of the credit functions of commercial banks in terms of innovation and industrial development of Kazakhstan's economy. 


\section{Literature Review}

Development loan, credit relations, the formation and the efficient use of credit resources are under scrutiny of the scientific sphere. Problems of development of credit rather extensively covered in the writings of foreign economists such as G. Akerlof (Akerlof, 1970), Jeong W. (Jeong, 1999), Lown C. S. (Lown, 1990), H. Minsky (Minsky, 1986), P.L. Rousseau (Rousseau, 2001), H. Schaller (Schaller 1993), J. Sinki (Sinki, 2009), Winker P. (Winker, 1999) and others. Significant contribution to the development of the theory of credit and credit system was made by Russian scientists and economists N.I. Valentseva (Valentseva, 2008), V.S. Gerashchenko (Gerashchenko, 1986), I.O. Lavrushin (Lavrushin, 2012), L.P. Krolivetskaya (Krolivetskaya, 2009), A.M. Tavasiev (Tavasiev, 2010) and others. Extensive research in the field of credit relations in our country are reflected in the works of modern Kazakh scientists such as: U.B. Baimuratov (Baimuratov, 2005), Z.D. Iskakova (Iskakova, 2014), N.K. Kuchukova (Kuchukova, 2011), G.S. Seytkasimov (Seytkasimov, 2007) and others.

In the work of Russian economists it is noted that "credit shall be based on the fundamental features of credit relations, which is a recurrence. In contrast to the funding does not require the repayment of money issued in the period, a credit system must be constructed in such a way that each issued loans always come back to the bank " (Gerashchenko, Lavrushin, 1986)

In the so-called post-crisis period, modern writers shifted their research on credit risk management of interaction between banks and borrowers, countercyclical nature of interaction between actors in the face of increasing integration and globalization processes.

Understanding that in a recession, only the active role of the state can support the banking sector and the priority sectors of the economy, as well as their relationship on the basis of sustainable interaction loan and repayment of loans, are the key to sustainable development of the progressive growth of the domestic economy is reflected in the publications of most scientists economists on this issue.

It should also be noted that at the present stage of development of scientific thought in Kazakhstan there are no fundamental research complex character, at the same time, various aspects of the problem have been considered in the works of Kazakhstan and foreign scientists, and that will be the scientific and methodological basis for the development of the theme, to achieve this goal and objectives of the study.

\section{Methods}

The study was based on the methods of system analysis and institutional analysis of the functioning of national innovation systems, including in the countries included in integration associations. During the implementation of this goal will be used dialectical and systematic methods and techniques of economic research: a comparison, synthesis, simulation, computational and analytical, expert, statistical and other methods.

A systematic analysis would address all the key areas of interaction between banking and real sectors of the economy not only in the national economic system, but also through the prism of the impact of globalization and the cyclical nature of the economy, burdening the interaction rapidly changing operating conditions of the subjects, increasing the risk of interaction that requires appropriate consideration when using a systematic approach.

Application of the method will identify the institutional features of the regulation, the tradition of cooperation sectors, national identity to encourage and support the process of interaction of these sectors in comparison with international experience. Institutional approach to determine and recommend to the parties concerned an effective model of sustainable interaction among the banking and real sectors of the economy in the context of cyclical development of the national and world economy.

\section{Results}

In 2010, Kazakhstan's economy showed positive changes. Thanks to the anti-crisis measures failed to prevent the economic recession in 2009 and ensure its growth in 2010. GDP growth in 2009 was 101,2\%, in 2010 - 107\%, in 2011 107,5\%, in $2012-105 \%$, in $2013-106 \%$. During this period increased macroeconomic indicators of the banking sector (Table 1). 
Table 1. Macroeconomic indicators of the banking sector

\begin{tabular}{|l|c|c|c|c|c|c|c|}
\hline Indicators & 2007 & 2008 & 2009 & 2010 & 2011 & 2012 & 2013 \\
\hline Total assets in \% to GDP & 90,9 & 74,1 & 67,9 & 55,2 & 46,5 & 45,7 & 45,3 \\
\hline Loans in \% to GDP & 56,5 & 46,5 & 44,9 & 34,8 & 31,9 & 32,8 & 33,1 \\
\hline Loans in \% to assets & 62,1 & 62,7 & 66,1 & 63,1 & 68,7 & 71,8 & 73,0 \\
\hline Credits to juridical persons in \% to GDP & 36,5 & 29,2 & 31,9 & 25,1 & 23,4 & 23,4 & 33,1 \\
\hline Credit juridical persons in \% to assets & 40,1 & 39,4 & 45,0 & 45,5 & 50,4 & 51,2 & 73,0 \\
\hline Deposits from individuals in \% to GDP & 11,1 & 9,2 & 11,1 & 10,1 & 9,9 & 11,1 & 11,4 \\
\hline Deposits from individuals in \% to liabilities & 12,2 & 12,4 & 16,4 & 18,2 & 21,3 & 24,3 & 25,3 \\
\hline Deposits of juridical persons in \% to GDP & 19,2 & 24,5 & 27,5 & 23,6 & 20,5 & 18,5 & 18,1 \\
\hline Deposits of juridical persons in \% to liabilities & 21,0 & 33,1 & 40,5 & 42,7 & 44,2 & 40,5 & 39,9 \\
\hline Calculated according to the National Bank of Kazakhstan & & & \\
\hline
\end{tabular}

Over the 2007-2013 period total assets of the banking sector increased by 1,3, including loans $-1,6$, of which are loans to legal entities - by 2,4. Deposits of individuals increased by 2,7, deposits of legal entities increased by 2,5 . During the study period there was a tendency to reduce both assets and loans and deposits in their relation to GDP.

In general, Kazakhstan's economy has experienced positive development trend, showing the financial crisis, however, in the banking and real sectors of the economy, some tension. This is due both to internal and external causes.

Kazakhstan's economy is highly integrated into the global economic system. Therefore, the global trends are also reflected in the Kazakh economy in general, and the banking system. As you know, during the 2010-2013 was observed a slowdown in the global economy growth, including the euro area, developing countries and China. According to the International Monetary Fund (IMF), it is expected that global growth will rise to 3,3\% in 2014 and 3,8\% in 2015. It is noted that the pace of global recovery lagged behind forecasts in recent years.

Internal negative factors continue to effect on the development of the national banking system. Persistent inflation, continuing outflow of capital abroad, undeveloped interbank market and interbank competition, lack of capitalization of the banking sector continue to hamper the activity of commercial banks.

Currently, in our opinion, in the ratio of bank credit and the real economy can be distinguished three main problems: Insufficient amount of credit resources; High cost; As well as a high concentration of credit risk in the real sector of the economy.

The first problem is illustrated by the data on the structure of investment sources of Kazakh enterprises. The share of bank loans for investment in fixed assets does not exceed 20\% (Figure 1).

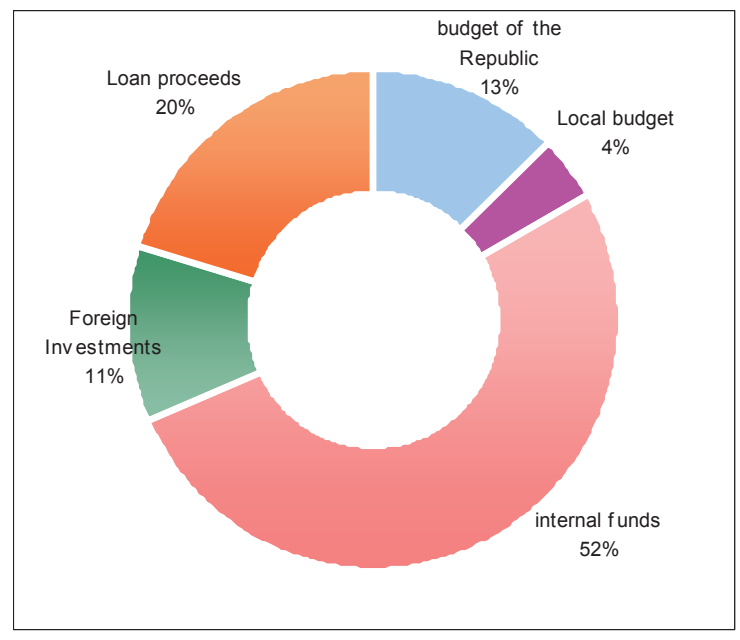

Figure 1. The share of bank loans in the amount of investment in fixed assets in the Republic of Kazakhstan in 2014, in $\%$

Source: Compiled on the basis of the source National Bank of Kazakhstan

Loans to the real sector in Kazakhstan decreased to $41 \%$ of gross domestic product (Figure 2). This situation is typical for 
other $\mathrm{CIS}$ countries.

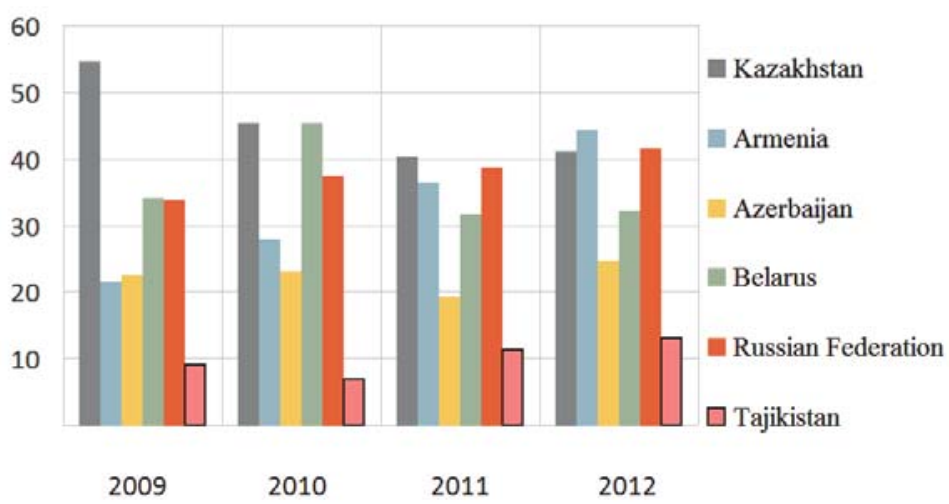

Figure 2. Domestic credits extended by banking sector of Kazakhstan and other CIS countries (in \% to GDP) Source: Compiled on the basis of the source International Monetary Fund

During the research period can be noted a steady increase in the share of domestic credit of the banking sector to the GDP in Armenia, Russia and Tajikistan. The smallest value of the share of domestic credit of the banking sector to GDP among the study group was observed in Tajikistan (less than 14\%).

One of the important issues is the resource support of Kazakh banks, its adequacy to participate in the investment process. Figure 3 shows the structure of liabilities of banks of the Republic of Kazakhstan for the period from 01.01.2010 to 01.11.2014, calculated on the basis of data provided by the National Bank of Kazakhstan. Since 2010 the activities of Kazakhstani banks are funded by corporates, public funds and funds raised by banks in the stock market. While the share of customer deposits (fixed term and non-fixed) increased from $47.9 \%$ to $74.6 \%$ in the total liabilities of Kazakh banks.

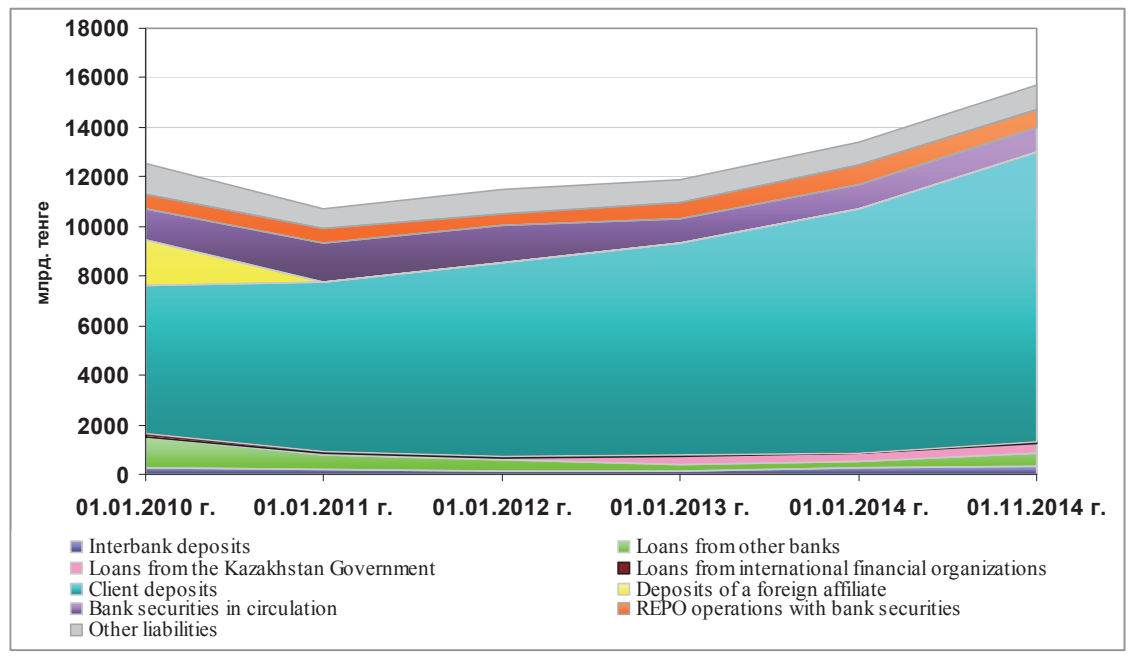

Figure 3. The structure of the liabilities of banks in Kazakhstan

Source: Compiled on the basis of the source National Bank of Kazakhstan

The second problem is related to the high cost of credit to the real economy subjects. At high rates in the real sector there is a problem of debt servicing. This is confirmed by comparing the profitability of enterprises and interest rates on bank loans (Fig. 4). 


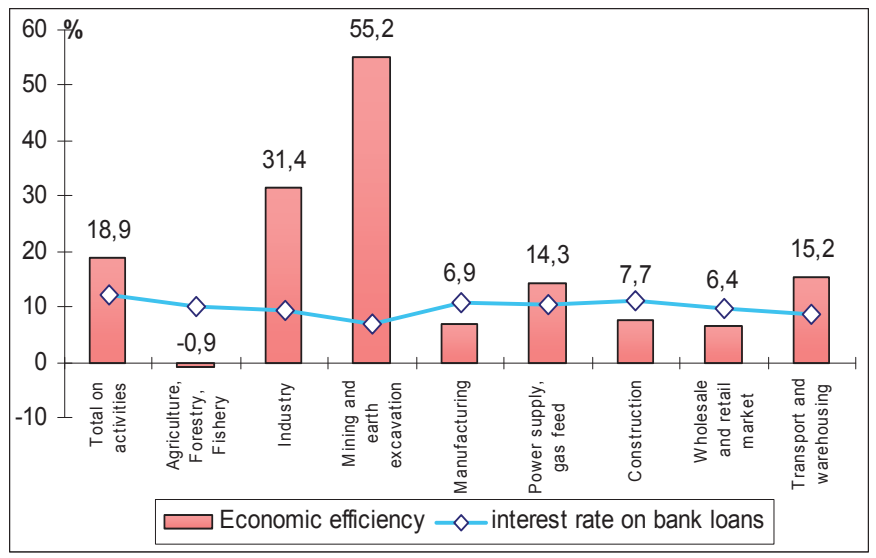

Figure 4. The Return of the real sector of the economy and interest rates on bank loans in 2014 (\%)

Source: Compiled on the basis of sources National Bank of Kazakhstan

Loans productive nature (loans to the real sector of the economy), which are provided by banks, the level of interest rates should be cheaper than the profitability of industries that use it. Consequently, manufacturing industries, agriculture in Kazakhstan etc. cannot afford to use credit services of Kazakh banks, the cost of which exceeds $10 \%$. High interest rate actually inhibits the growth of long-term loans, although many sectors of the economy of Kazakhstan are in need of financial resources for modernization and structural changes.

The third problem is related to the presence of high credit risks in the real economy. This is evidenced by the data on the volume of overdue debts of Kazakh banks (Figure 5).

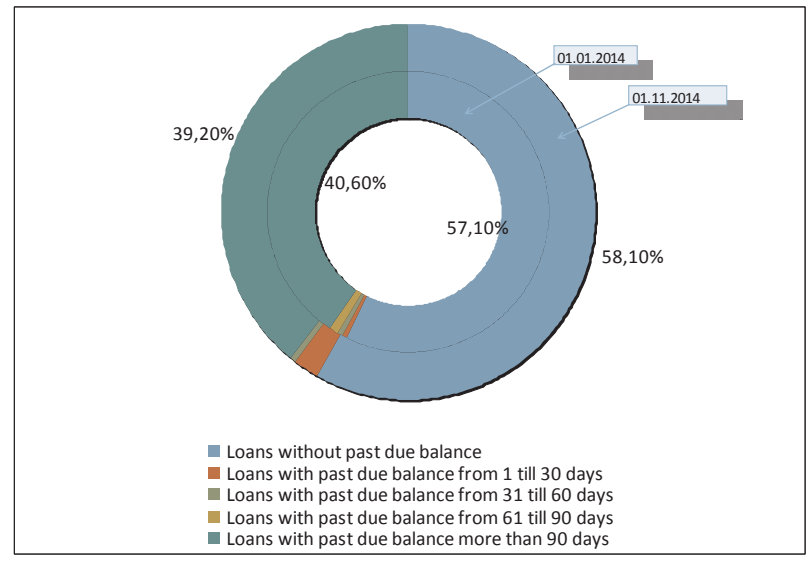

Figure 5. The structure of bank loans to legal entities

Source: Compiled on the basis of the source National Bank of Kazakhstan

The corporate sector, which is the main borrower of banks shows slowdown in business activity and the resulting slowdown in gross income, which, in turn, potentially reducing their ability to service its debt obligations and limits the ability to restore the quality of problem debts of banks. The structural weakness of the sector of small and medium-sized businesses and reducing its contribution to GDP growth has become one of the factors increasing the concentration of credit risk in the loan portfolio of banks.

According to the Concept of development of the financial sector of the Republic of Kazakhstan until 2030 one of the issues for further development of the banking sector is to solve the existing problems of high levels of non-performing loans and a shortage of long-term funding sources that provide a disincentive for banks' credit activity [7]. To solve the problem of poor quality assets in 2012 were put in place several mechanisms to "clean up" the balance of the banks: the sale of distressed assets of JSC "Fund of problem loans" and the Bank's subsidiary, the conditions for forgiveness of bad debts before the end of 2015 without incurring additional tax liabilities for banks, the limits for the share of non-performing loans in the loan portfolio of banks and others. 
Thus, the analysis of the data revealed the following:

- There is a minimal part of the banking system in the financing of capital investments;

- High interest rates make unprofitable investments in long-term real projects;

- Excessively rapid reorientation of Kazakh banks with lending to the real production of consumer demand for loans, which, as we know, is focused primarily on the purchase of imported goods;

- Insufficient activity of systemically important banks in lending to the real sector, as well as small and mediumsized businesses at their absolute dominance in the assets and profits of the banking system.

\section{Discussion}

In order to solve the existing problems of bank lending to the real sector of the economy is necessary to adopt a number of measures, such as interest rate subsidies to fund the priorities of socio-economic development or administrative restrictions of rising interest rates, the provision of state guarantees for loans to the real sector of the economy, the decline in the share of non-performing assets banks' balance sheets through the restructuring of non-performing loans, the development of the regional elements of the banking system, etc.

\section{Conclusion}

The analysis shows that, despite the relatively rapid recovery of banking operations in the post-crisis period, the banking sector are still not enough active in lending to the economy. The banking sector needs to modernize and revise the strategic objectives of the banking policy.

\section{References}

Akerlof G. (1970) The Market for Lemons: Quality Uncertainty and the Market Mechanism. - Quarterly Journal of Economics, August 1970,85, p. 488-500.

Baimuratov U.B. (2005) Money and Finance: nonlinear system. - Almaty, 2005.

Data from the International Monetary Fund/ http://www.imf.org/ date treatment 09/12/2014.

Gerashchenko V.S. (1986) Organization and planning of the loan. - M .: Finance and statistics, 1986.

Iskakova Z.D. (2014) Financial and credit system of Kazakhstan in a market economy. - Astana: MES RK, 2014 - 237 p.

Jeong W. (1999) Three Essays on the Relationship Between the Banking Sector, the Real Sector, and the Political Environment. Morgantown, West Virginia, 1999. -90p.

Krolivetskaya L.P. (2009) Banking: Credit activities of commercial banks. - M.: KNORUS, 2009.

Kuchukova N.K. (2011) Development of regional financial infrastructure as an important factor lifting and restructuring of the real sector of the economy of Kazakhstan. Astana, 2011.

Lavrushin O.I. (2012) The role of credit and modernization activities of banks in lending. - M.: KNORUS, 2012 -272p.

Lown C. S. (1990) Banking and the Economy: What Are the Facts?// Economic Review.: Federal Reserve Bank of Dallas.- September.1990.- pp. 1-14.

Minsky H. (1986) Money and Crisis in Schumpeter and Keynes. - In The Economic Law of Motion of Modern Society: A Marx - KeynesSchumpeter Centennial, Wagener HJ and eds. Cambridge, UK: Cambridge University Press, 1986.

On investments in fixed assets in the Republic of Kazakhstan. 8 series. Agency of the Republic of Kazakhstan on Statistics. http://www.stat.gov.kz/faces/wcnav_externalld/ date treatment 15/12/2014

Rousseau P.L. (2001) Financial Systems, Economic Growth and Globalization. - NBER Working Paper Series, June 2001, Working Paper 8223, p. 1-53.

Schaller H. (1993) Asymmetric Information, Liquidity Constraints, and Canadian Investment. - Canadian Journal of Economics, August 1993, 26, p. 552 - 574.

Seytkasimov G. S/ (2007) Banking. - Astana. 2007.

Sinki J. (2009) Financial management in commercial bank. - M., 2009.

Statistical Bulletin of the National Bank of the Republic of Kazakhstan for 2000-2014 years. - http://www.nationalbank.kz / cont / treatment date $11 / 12 / 2014$

Tavasiev A.M. (2010) Bank lending. - M.: INFRA, 2010.

The concept of development of the financial sector of the Republic of Kazakhstan till 2030, approved by the Government of the Republic of Kazakhstan "29" August 2014 number 954.

Valentseva N.I. (2008), Krasavina L.N. Russian financial market: the problem of increasing competitiveness and the role of innovation in economic development // Money and Credit, 2008. - №3. - pp. 62-75.

Winker P. (1999) Sluggish adjustment of interest rates and credit rationing: an application of unit root testing// Applied Economics.-1999.Mar.- Vol. 31 Issue 3.- pp. 267. 